\title{
Pemanfaatan AES dengan Key Dinamis sebagai Metode Pengamanan Data pada Smart Card
}

\author{
Noprianto*, Vivi Nur Wijayaningrum, Rudy Ariyanto \\ Jurusan Teknologi Informasi, Politeknik Negeri Malang \\ Jalan Soekarno Hatta 9, Malang \\ *e-mail: noprianto@polinema.ac.id
}

(received: 18 Mei, revised: 24 Juli 2021, accepted: 3 Agustus 2021)

\begin{abstract}
Abstrak
Terjadinya pandemi Covid-19 di hampir seluruh belahan dunia, termasuk Indonesia, menjadikan masyarakat mempunyai gaya hidup baru dalam bertransaksi untuk mencegah penularan virus sesuai anjuran Pemerintah. Semua transaksi cenderung dilakukan secara non tunai dengan memanfaatkan teknologi smart card untuk menghindari adanya kontak fisik dengan orang lain. Tingginya penggunaan smart card pada berbagai bidang untuk mendukung aktivitas sehari-hari menyebabkan rawannya terjadi pencurian data di dalam smart card oleh pihak yang tidak bertanggung jawab. AES sebagai algoritma kriptografi dapat digunakan untuk mengamankan data di dalam smart card dengan melakukan enkripsi data sebelum data yang bersifat rahasia tersebut disimpan ke dalam smart card. Untuk meningkatkan keamanan data, diusulkan sebuah mekanisme penggunaan key yang bersifat dinamis dengan memanfaatkan Unique Identifier (UID) setiap smart card. Dengan demikian, key yang digunakan untuk melakukan enkripsi dan dekripsi data dibentuk berdasarkan UID dan berbedabeda untuk setiap smart card. Hasil pengujian menunjukkan bahwa penggunaan AES dengan key yang bersifat dinamis ini mampu mengamankan data 40 byte plainteks menjadi 48 byte cipherteks, dengan rata-rata waktu komputasi sebesar $71.2 \mathrm{~ms}$ untuk penulisan data dan $89.4 \mathrm{~ms}$ untuk pembacaan data menggunakan key 128 bit, $70.8 \mathrm{~ms}$ untuk penulisan data dan $88 \mathrm{~ms}$ untuk pembacaan data menggunakan key 192 bit, dan 72 ms untuk penulisan data dan 88.4 ms untuk pembacaan data menggunakan key 256 bit. Waktu komputasi ini hanya mempunyai selisih sekitar 2 ms dibandingkan dengan penulisan dan pembacaan data tanpa mekanisme enkripsi dan dekripsi.
\end{abstract}

Kata kunci: covid-19, dekripsi, enkripsi, keamanan, kriptografi

\begin{abstract}
The occurrence of the Covid-19 pandemic in almost all parts of the world, including Indonesia, has made people have a new lifestyle in transactions to prevent transmission of the virus as recommended by the Government. All transactions tend to be carried out in non-cash using smart card technology to avoid physical contact with other people. The high use of smart cards in various fields to support daily activities makes it prone to data theft on the smart card by irresponsible parties. AES as a cryptographic algorithm can be used to secure data on the smart card by encrypting the data before the confidential data is stored on the smart card. To improve data security, a dynamic key usage mechanism is proposed by utilizing the Unique Identifier (UID) of each smart card. Thus, the key used to encrypt and decrypt data is formed based on the UID and is different for each smart card. The test results show that the use of AES with a dynamic key is able to secure 40 bytes of plaintext to 48 bytes of ciphertext, with an average computation time of $71.2 \mathrm{~ms}$ for writing data and $89.4 \mathrm{~ms}$ for reading data using 128-bit keys, $70.8 \mathrm{~ms}$ for writing data and $88 \mathrm{~ms}$ for reading data using a 192-bit key, and $72 \mathrm{~ms}$ for writing data and $88.4 \mathrm{~ms}$ for reading data using a 256-bit key. This computation time only has a difference of about $2 \mathrm{~ms}$ compared to writing and reading data without encryption and decryption mechanisms.
\end{abstract}

Keywords: covid-19, decryption, encryption, security, cryptography

\section{Pendahuluan}

Teknologi smart card mengalami perkembangan yang sangat pesat. Hal ini dikarenakan smart card menawarkan fitur keamanan seperti kontrol akses, serta kemampuan untuk melakukan berbagai 
fungsi lainnya sehingga menjadikan smart card dapat diterapkan untuk berbagai aplikasi di kehidupan sehari-hari [1]. Salah satu contoh penggunaan smart card adalah KTP elektronik (e-KTP) yang digunakan untuk menyimpan data pribadi setiap penduduk Indonesia [2]. Di dalam e-KTP terdapat chip berbasis mikroprosesor, sehingga dengan adanya teknologi smart card ini, e-KTP tidak hanya dapat dimanfaatkan sebagai autentikasi identitas saja, tetapi juga dapat mengakomodasi fungsi-fungsi lainnya [3].

Penggunaan smart card yang juga sering ditemui di Indonesia adalah electronic money (emoney) sebagai alat pembayaran pengganti uang tunai [4][5]. Keuntungan penggunaan e-money adalah mengurangi risiko kehilangan uang dan memberikan kemudahan transaksi bagi pengguna karena nominal yang dibayarkan menggunakan e-money pasti sesuai dengan tagihan pembayaran, tanpa perlu ada uang kembalian. Selain itu, adanya pandemi Covid-19 saat ini menyebabkan perilaku masyarakat Indonesia juga berubah ketika melakukan transaksi jual beli. Masyarakat cenderung memilih menggunakan e-money dan e-wallet untuk melakukan transaksi pembayaran guna menghindari adanya kontak fisik dengan orang lain saat melakukan transaksi pembayaran [6].

Saat ini, penggunaan smart card juga banyak dimanfaatkan untuk sistem parkir, baik untuk memudahkan pencatatan kendaraan yang keluar atau masuk lahan parkir [7], maupun untuk proses pembayaran parkir oleh pelanggan [8]. Penggunaan smart card untuk sistem parkir ini dapat mengatasi berbagai permasalahan yang terjadi pada sistem parkir konvensional, antara lain lamanya durasi pelayanan pelanggan, tingginya penggunaan karcis parkir, dan tidak adanya fitur untuk memulihkan data transaksi [9]. Selain itu, tindakan pencurian kendaraan bermotor yang terparkir juga dapat diminimalkan dengan melakukan monitoring kendaraan yang keluar dan masuk gerbang parkir.

Dengan adanya data pribadi yang bersifat rahasia tersimpan di dalam e-KTP maupun e-money, maka perlu adanya mekanisme pengamanan data yang dilakukan pada smart card untuk menjaga kerahasiaan data yang tersimpan di dalamnya sehingga data tersebut tidak dapat dibaca oleh pihak yang tidak bertanggung jawab [10]. Untuk mengamankan data yang tersimpan pada smart card, berbagai teknik dapat dilakukan, salah satunya adalah dengan menggunakan kriptografi. Terdapat beberapa algoritma kriptografi yang sering digunakan, antara lain Data Encryption Standard (DES), Triple Data Encryption Standard (3DES), dan Advanced Encryption Standard (AES). Perbedaan utama antara ketiganya adalah panjang key yang digunakan untuk proses enkripsi dan dekripsi. AES menggunakan tiga jenis panjang key yaitu 128 bit, 192 bit, dan 256 bit, sementara DES menggunakan 56 bit, dan 3DES menggunakan 168 bit. Secara teori, semakin panjang key yang digunakan, maka semakin tinggi tingkat keamanan yang diberikan untuk proses enkripsi data [11]. Algoritma kriptografi lainnya yang juga sering digunakan adalah Rivest Shamir Aldeman (RSA). Pada umumnya, key yang digunakan RSA mempunyai panjang 1024 bit dan 2048 bit. Dengan semakin panjangnya key yang digunakan pada RSA, tentu semakin tinggi tingkat keamanan data, namun waktu yang diperlukan untuk melakukan proses enkripsi dan dekripsi juga menjadi semakin tinggi. RSA terbukti membutuhkan waktu komputasi lebih lebih tinggi dibandingkan AES dan DES [12][13].

Pada penelitian sebelumnya, pemanfaatan AES dengan mode Cipher Block Chaining (CBC) terbukti dapat digunakan untuk mengamankan data saat proses pengiriman dari perangkat Internet of Things (IoT) ke aplikasi [14]. Sementara itu, pada penelitian ini, AES digunakan untuk mengamankan data pada smart card. Namun, karena AES merupakan algoritma yang menggunakan symmetric key, maka untuk meningkatkan proses pengamanan data, diusulkan penggunaan key bersifat dinamis berdasarkan UID setiap kartu. Dengan demikian, meskipun key yang digunakan pada AES bersifat symmetric, key yang digunakan pada setiap kartu akan berbeda-beda menyesuaikan dengan UID-nya. Penggunaan teknik kriptografi untuk proses enkripsi data pada smart card diharapkan dapat meningkatkan keamanan data yang tersimpan di dalam smart card. Selain itu, pemilihan algoritma AES untuk proses enkripsi data juga diharapkan tidak memberikan pengaruh yang signifikan terhadap waktu komputasi untuk proses pembacaan dan penulisan data pada smart card.

\section{Tinjauan Literatur}

Penggunaan algoritma DES yang telah dimodifikasi untuk mengamankan data pada smart card telah dilakukan oleh Sison, dkk [15]. Proses enkripsi diawali dengan mengubah key hexadesimal sepanjang 64 bit menjadi bilangan biner, kemudian hasilnya dikurangi sehingga menjadi 56 bit dan dikirimkan ke substitusi Ganjil-Genap. Pada proses subtitusi Ganjil-Genap dilakukan penggantian 
nilai 1 untuk setiap posisi genap dan 0 untuk setiap posisi ganjil di blok 56 bit. Selanjutnya, blok 56 bit tersebut dibagi menjadi dua bagian dengan masing-masing berisi 28 bit bilangan. Pada setiap bagian dilakukan left shift dengan menggeser bilangan ke kiri sebanyak satu kali. Kedua bagian tersebut digabungkan kembali dan direduksi menjadi 48 bit, lalu diubah kembali menjadi hexadesimal. Bilangan 48 bit inilah yang digunakan ini menjadi key pertama. Selanjutnya, pembuatan key dilanjutkan hingga 16 putaran. Adanya substitusi Ganjil-Genap pada penelitian ini memastikan bahwa meskipun data ditahan oleh jaringan lain maupun dialihkan ke tujuan lain, integritas dan kerahasiaan data tetap dapat terjamin [15]. Namun, DES terbukti sangat tidak aman dan tidak dapat diandalkan, sehingga kemudian muncul algoritma lainnya yaitu 3DES atau Triple DES untuk mengatasi permasalahan pada DES [16].

Pada penelitian yang dilakukan oleh Darwito, Yuliana, dan Soelistijorini, 3DES digunakan untuk mengamankan data riwayat kesehatan yang tersimpan di cloud. Hal ini bertujuan untuk memungkinkan penyimpanan dan pertukaran data riwayat pasien sehingga dapat diakses oleh berbagai penyedia layanan kesehatan seperti puskemas, rumah sakit, maupun perusahaan asuransi. Selain itu, smart card juga digunakan untuk mengontrol akses informasi pasien. Sebelum menerapkan 3DES untuk enkripsi data, tiga buah key (K1, K2, dan K3) perlu dibangkitkan terlebih dahulu. Selanjutnya, enkripsi plainteks dapat dilakukan dengan menggunakan DES tunggal menggunakan K1. Setelah itu, dekripsi dilakukan menggunakan K2 terhadap hasil enkripsi pada langkah sebelumnya. Dengan menggunakan K3, dilakukan enkripsi kembali terhadap hasil dekripsi dari langkah sebelumnya, sehingga diperoleh cipherteks. Hasil pengujian avalanche effect yang dilakukan menunjukkan bahwa sistem tersebut memenuhi syarat keamanan dengan nilai 51.4\% [17]. 3DES terbukti mampu mengungguli DES, namun 3DES ini juga mempunyai keterbatasan pada ukuran key yang digunakan, yaitu 56 bit sesuai dengan standar DES. Selain itu, key enkripsi harus diganti setiap 32GB transfer data untuk menghindari terjadinya kebocoran data [16]. Beberapa penelitian menyebutkan bahwa AES bekerja lebih baik dibandingkan DES dan 3DES [16][18]. AES memberikan tingkat keamanan yang tinggi karena menggunakan key dengan ukuran lebih panjang dibandingkan dua algoritma lainnya [19].

Penelitian ini menggunakan algoritma AES dengan key dinamis untuk mengamankan data pada smart card. Kebaruan yang ditawarkan pada penelitian ini adalah penerapan key yang bersifat dinamis saat melakukan proses enkripsi dan dekripsi data pada smart card. Pada umumnya, penelitianpenelitian sebelumnya menggunakan sebuah key yang bersifat statis, artinya key yang digunakan untuk proses enkripsi dan dekripsi bersifat tetap sesuai dengan nilai yang telah ditentukan. Pada penelitian ini, key dinamis yang digunakan untuk melakukan proses enkripsi dan dekripsi data dibentuk berdasarkan kode alfanumerik (UID) yang dimiliki oleh masing-masing smart card. Setiap kartu mempunyai nilai unik berukuran empat atau tujuh byte yang bersifat sebagai identitas dari setiap kartu. Dengan demikian, key yang digunakan oleh setiap kartu untuk proses enkripsi dan dekripsi nantinya akan menjadi berbeda-beda sesuai dengan UID yang dimiliki oleh setiap kartu tersebut.

\section{Metode Penelitian}

Penerapan teknologi smart card pada penelitian ini membutuhkan beberapa perangkat untuk proses pengembangan dan analisis hasil. Perangkat keras yang dibutuhkan antara lain CPU $2.5 \mathrm{GHz}$ Intel Core i5, memori DDR3 16 GB, Intel HD Graphics 40001536 MB, sistem operasi MacOS Mojave, media penyimpanan SSD 512 GB, smart card Mifare 1K, dan reader NFC ACR122U SAM. Perangkat lunak yang digunakan adalah Java 8, Intellij IDEA Ultimate 2021.1, dan Gitlab.

Pada penelitian ini, tahapan pembacaan maupun penulisan data pada smart card hampir sama seperti cara mengakses smart card pada umumnya. Namun, terdapat penambahan proses enkripsi dan dekripsi data dengan menggunakan key dinamis untuk meningkatkan level keamanan data. Gambar 1 menunjukkan tahapan yang digunakan untuk melakukan penulisan data ke dalam smart card. 


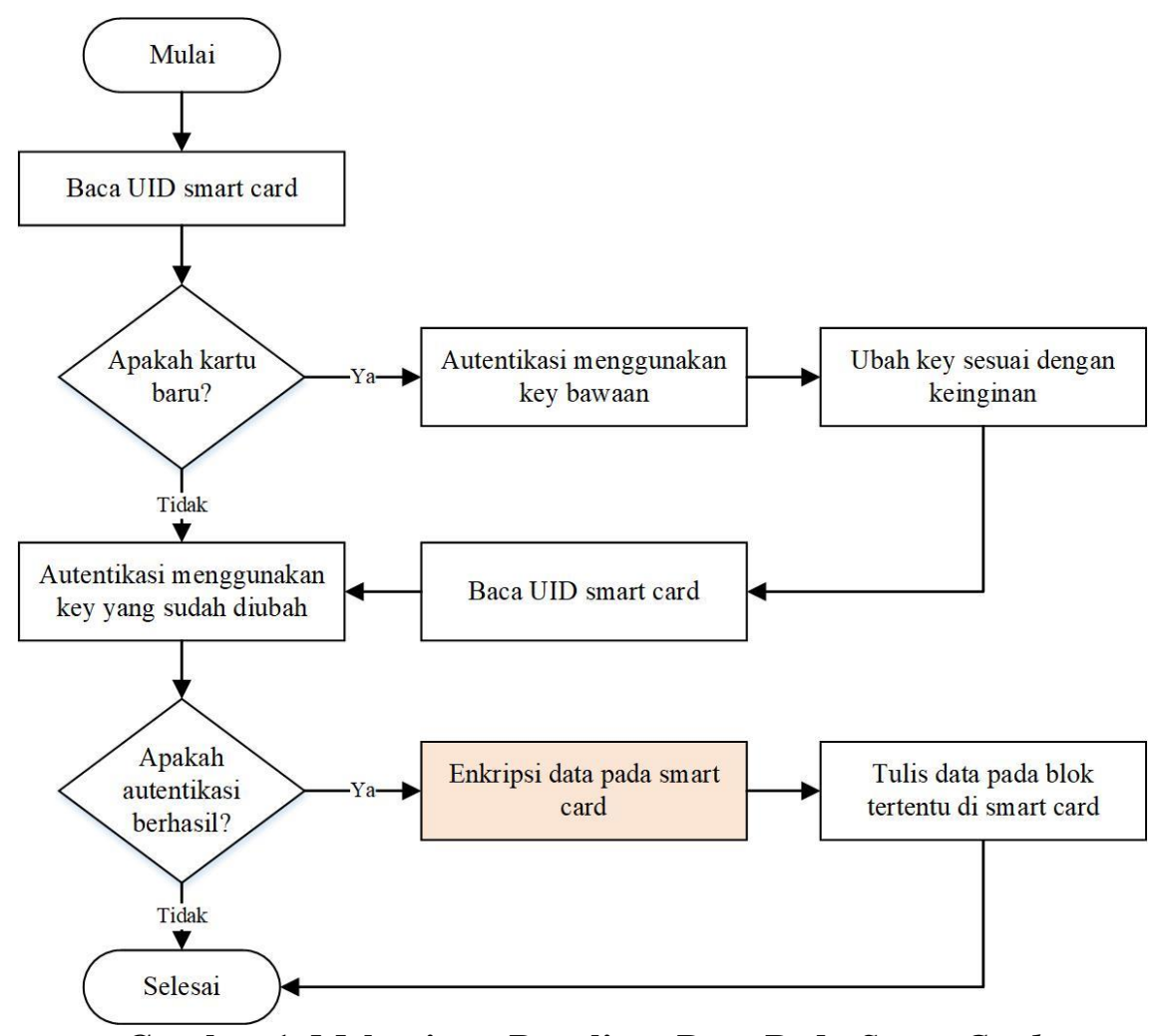

Gambar 1. Mekanisme Penulisan Data Pada Smart Card

Pada Gambar 1, ditunjukkan bahwa penulisan data pada smart card dilakukan dengan mendeteksi UID tujuan sehingga dapat diketahui jenis tag yang digunakan. Apabila tag kartu sudah diketahui, selanjutnya perlu dibedakan apakah kartu tersebut merupakan kartu baru atau tidak. Jika kartu yang dideteksi tersebut adalah kartu baru, artinya belum pernah dilakukan pengubahan key pada kartu tersebut, maka pengguna harus mengubah key terlebih dahulu sebelum menggunakan kartu tersebut. Kemudian, autentikasi dan enkripsi data dapat dilakukan untuk melakukan pengamanan data sebelum data tersebut dituliskan ke dalam smart card.

Ketika data yang tersimpan tersebut diperlukan untuk didistribusikan ke aplikasi-aplikasi lain yang membutuhkan, maka proses pembacaan data perlu dilakukan dengan menggunakan reader. Gambar 2 menunjukkan tahapan yang digunakan untuk melakukan pembacaan data pada smart card.

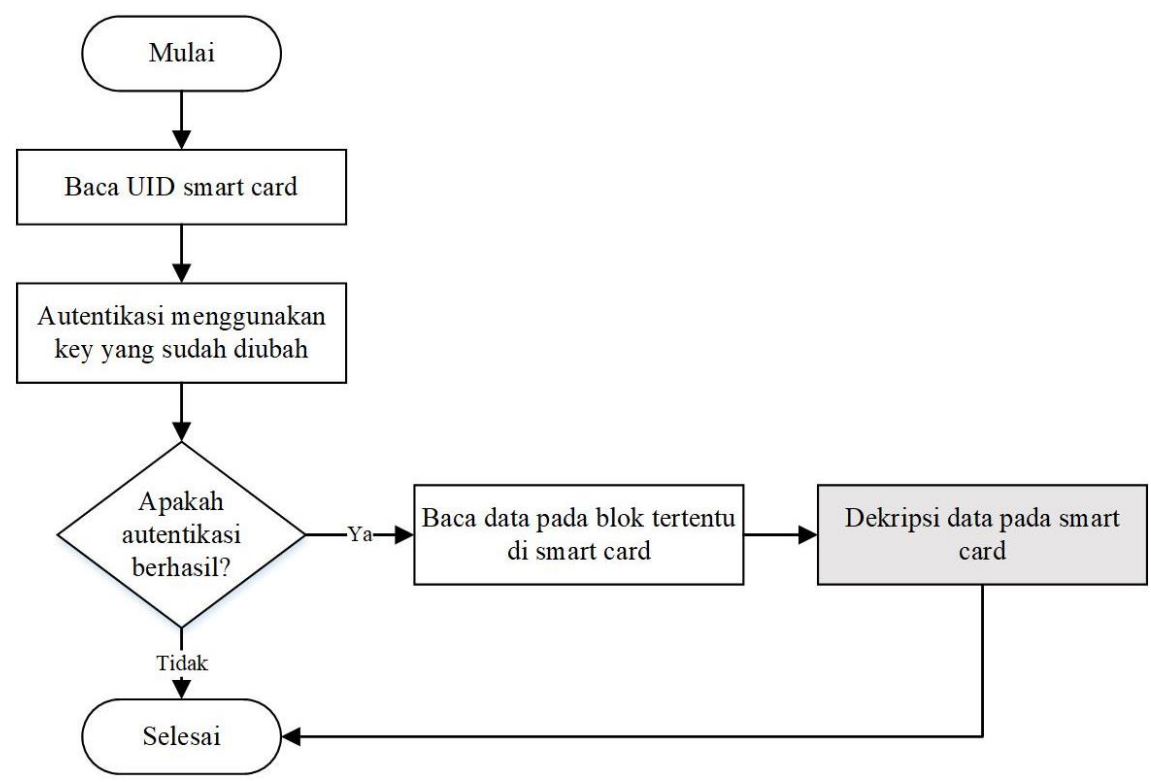

Gambar 2. Mekanisme Pembacaan Data Pada Smart Card 
Pada Gambar 2, ditunjukkan bahwa pembacaan data pada smart card diawali dengan mendeteksi tag kartu dengan cara mendapatkan UID kartu terlebih dahulu. Setelah itu, autentikasi dapat dilakukan menggunakan key yang digunakan untuk proses pembacaan data. Apabila proses autentikasi berhasil, maka pembacaan data dapat dilakukan pada sector dan blok tertentu di dalam smart card. Karena data yang terbaca tersebut masih berbentuk cipherteks, selanjutnya perlu diubah ke dalam bentuk plainteks terlebih dahulu dengan proses dekripsi data.

\section{Hasil dan Pembahasan}

Data yang digunakan pada penelitian ini terdiri dari beberapa field untuk kebutuhan sistem parkir, yaitu Tanda Nomor Kendaraan Bermotor (TNKB), tanggal transaksi, status masuk, kode gate, Nomor Induk Pegawai (NIP), kedaluwarsa kartu, dan status kartu [20]. Contoh data yang diisikan pada setiap field ditunjukkan pada Tabel 1 .

Tabel 1. Data pada Smart Card

\begin{tabular}{ll}
\hline \multicolumn{1}{c}{ Field } & \multicolumn{1}{c}{ Data } \\
\hline TNKB & AB2039YQ \\
Tanggal transaksi & 2021-05-06 16:12:00 \\
Status masuk (keluar/masuk) & 1 \\
Kode gate & 255 \\
NIP & 198911082019031020 \\
Kedaluwarsa kartu & $2021-05-0616: 12: 00$ \\
Status kartu (aktif/masuk) & 1 \\
\hline
\end{tabular}

Untuk dapat disimpan ke dalam smart card, data tersebut harus diubah ke dalam format hexadesimal terlebih dahulu agar lebih mudah dalam merepresentasikan, meskipun nantinya format yang digunakan ketika data disimpan ke dalam kartu berbentuk byte. Secara keseluruhan, panjang data yang diperlukan untuk menyimpan data pada Tabel 1 adalah 40 byte. Hasil transformasi data tersebut ke dalam format hexadesimal ditunjukkan pada Tabel 2.

Tabel 2. Hasil Transformasi Data ke dalam Format Hexadesimal

\begin{tabular}{ll}
\hline \multicolumn{1}{c}{ Field } & \multicolumn{1}{c}{ Data (Hexadesimal) } \\
\hline TNKB & 30304142323033395951 \\
Tanggal transaksi & $6093 \mathrm{~B} 2 \mathrm{E} 0$ \\
Status masuk (keluar/masuk) & 01 \\
Kode gate & $00 \mathrm{FF}$ \\
NIP & 313938393131303832303139303331303230 \\
Kedaluwarsa kartu & $6093 \mathrm{~B} 2 \mathrm{E} 0$ \\
Status kartu (aktif/masuk) & 01 \\
\hline
\end{tabular}

Selanjutnya, data yang telah diubah ke dalam bentuk hexadesimal tersebut dienkripsi menggunakan AES. Meskipun AES merupakan algoritma enkripsi yang menggunakan symmetric key, artinya key yang digunakan untuk melakukan enkripsi dan dekripsi adalah key yang sama, namun key yang digunakan pada penelitian ini merupakan key dinamis yang dibentuk berdasarkan UID smart card. Dengan demikian, key yang digunakan oleh setiap kartu nantinya akan menjadi berbeda-beda sesuai dengan UID setiap kartu tersebut.

Untuk membentuk key A dengan panjang 6 byte yang bersifat dinamis, digunakan empat byte UID smart card dan dua byte data yang bisa didefinisikan sesuai dengan kebutuhan (user data). Mekanisme pembentukan key A adalah melakukan reverse UID smart card dengan cara membaca secara terbalik semua angka (hexadesimal) pada UID, kemudian dikombinasikan dengan user data. Misalnya UID sebuah smart card bernilai A9 C3 1C E5, setelah dilakukan reverse menjadi 5E C1 3C 9A. Empat byte UID yang telah di-reverse tersebut digunakan sebagai byte kedua sampai kelima dari key A, sedangkan byte pertama dan terakhir dari key A diperoleh dari user data. Misalnya user data 
yang digunakan adalah 20 dan 21 (desimal), yang merepresentasikan tahun saat ini, kemudian diubah ke dalam format hexadesimal menjadi 14 dan 15. Dengan demikian, key A untuk smart card tersebut adalah 14 5E C1 3C 9A 15. Tentunya key A ini akan berbeda untuk kartu yang lain karena UID setiap kartu berbeda-beda dan pembentukan key A bergantung pada UID. Mekanisme pembentukan key A ditunjukkan pada Gambar 3.

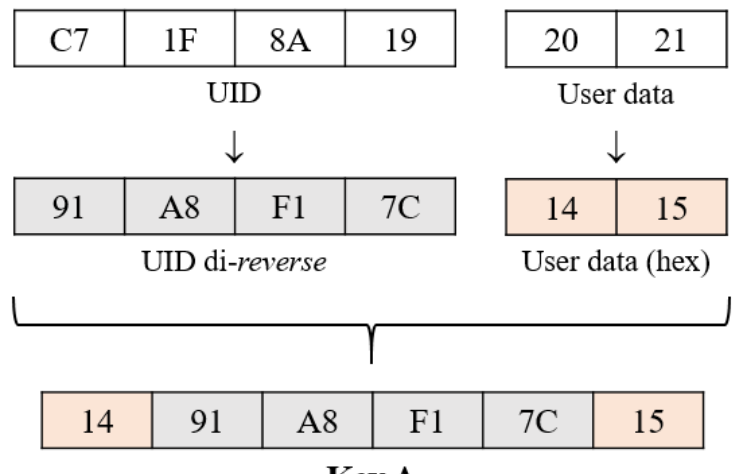

Key A

Gambar 3. Mekanisme Pembentukan Key A

Selanjutnya, pembentukan key B juga dilakukan dengan cara yang hampir sama seperti pembentukan key A. Hal yang membedakan adalah pola yang digunakan saat mengombinasikan empat byte UID yang telah di-reverse dengan dua byte user data. Untuk membentuk key $\mathrm{B}$, dua byte pertama dari UID yang telah di-reverse digunakan sebagai byte pertama dan kedua dari key $\mathrm{B}$, kemudian dua byte yang tersisa digunakan sebagai byte kelima dan keenam dari key $\mathrm{B}$, sedangkan byte ketiga dan keempat dari key B diperoleh dari user data. Dalam kasus ini, UID smart card yang digunakan bernilai sama seperti pada penjelasan pembentukan key A karena kartu yang digunakan tetap, sehingga diperoleh UID yang telah di-reverse bernilai 5E C1 3C 9A. Selanjutnya, user data yang digunakan adalah bulan dan tanggal yaitu 03 dan 18 (desimal), kemudian diubah ke dalam format hexadesimal menjadi 03 dan 12. Dengan demikian, key B untuk smart card tersebut adalah 5E C1 0312 3C 9A. Mekanisme pembentukan key B ditunjukkan Gambar 4.

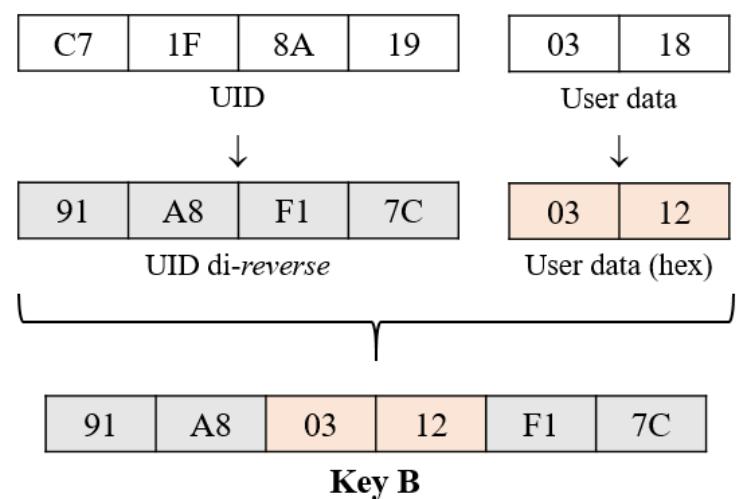

Gambar 4. Mekanisme Pembentukan Key B

Beberapa key yang digunakan dalam penelitian ini berukuran 128 bit, 192 bit, dan 256 bit. Key dibentuk dengan mengombinasikan key A, key B, dan UID. Dalam hal ini, key A dan key B merupakan key yang digunakan untuk proses autentikasi dan UID merupakan nomor unik yang tersedia pada setiap kartu. Terdapat beberapa kombinasi key yang digunakan pada penelitian ini, antara lain key 16 byte atau 128 bit, key 24 byte atau 192 bit, dan key 32 byte atau 256 bit.

\subsection{Key 16 byte atau 128 bit}

Pembentukan key 128 bit dilakukan dengan cara mengombinasikan key A, UID, dan key B. Diketahui UID sebuah kartu adalah A9 C3 1C E5, maka key A dan key B dapat dibentuk dengan 
menggunakan cara yang sama seperti yang telah diilustrasikan pada Gambar 3 dan Gambar 4, sehingga 14 5E C1 3C 9A 15 sebagai key A dan 5E C1 03 12 3C 9A sebagai key B. Ilustrasi penyusunan key 128 bit menggunakan key A, UID, dan key B ditunjukkan pada Gambar 5.

\begin{tabular}{|c|c|c|}
\hline 14 5E C1 3C 9A 15 & A9 C3 1C E5 & 5E C1 03 12 3C 9A \\
\hline Key A & UID & Key B \\
\hline \multicolumn{3}{|c|}{ Key 128 bit } \\
\hline
\end{tabular}

\section{Gambar 5. Mekanisme Penyusunan Key 128 Bit}

Selanjutnya, key 128 bit yang telah terbentuk tersebut digunakan untuk melakukan enkripsi data pada Tabel 2 yang telah tersimpan di dalam smart card. Hasil enkripsi menggunakan key 128 bit adalah DB 3E EF 5138 2D 29 10 5A 9483 0E 33 2B 06 0E 9F 70956391 D4 13 F2 9B D2 A8 6B E8 FE 1E 02 FC C6 5E DB 7F DF 98 8C C4 895588 AC C4 5D 47. Terlihat bahwa setelah proses enkripsi, data yang awalnya mempunyai panjang 40 byte tersebut berubah menjadi 48 byte.

\subsection{Key 24 byte atau 192 bit}

Pembentukan key 192 bit dilakukan dengan cara mengombinasikan key A dan key B saja, tanpa UID. Hal ini dikarenakan pembentukan key 24 byte dapat dilakukan dengan menggunakan key A dan key B masing-masing sebanyak dua kali. Dalam hal ini, penyusunan key 192 bit dilakukan dengan mengombinasikan key A, key B, key B, dan key A seperti yang diilustrasikan pada Gambar 6.

\begin{tabular}{|c|c|c|c|}
\hline 14 5E C1 3C 9A 15 & 5E C1 03 12 3C 9A & 5E C1 03 12 3C 9A & 14 5E C1 3C 9A 15 \\
\hline Key A & Key B & Key B & Key A \\
\hline
\end{tabular}

\section{Gambar 6. Mekanisme Penyusunan Key 192 Bit}

Selanjutnya, key 192 bit yang telah terbentuk tersebut juga digunakan untuk melakukan enkripsi data pada Tabel 2, sehingga cipherteks yang dihasilkan adalah 6C 48 F7 8F 289298279637 3D 0B EA 73 9F 3663 6D 2E 8241 3A 5780 E0 3E 38 EA EE FE 13965701 D7 1F 76 D0 D9 DE 2337 C9 30 5B D0 03 D4. Pada kasus ini, panjang data setelah enkripsi sama seperti panjang data hasil enkripsi menggunakan key 128 bit, yaitu 48 byte, yang menunjukkan bahwa cipherteks lebih panjang dari plainteks.

\subsection{Key 32 byte atau 256 bit}

Pembentukan key 256 bit dilakukan dengan cara mengombinasikan key A, key B, dan UID masing-masing sebanyak dua kali sehingga terbentuk key sepanjang 32 byte. Ilustrasi penyusunan key 256 bit menggunakan key A, key B, dan UID ditunjukkan pada Gambar 7.

\begin{tabular}{|c|c|c|c|c|c|}
\hline 14 5E C1 3C 9A 15 & 5E C1 03 12 3C 9A & A9 C3 1C E5 & A9 C3 1C E5 & 5E C1 03 12 3C 9A & 14 5E C1 3C 9A 15 \\
\hline Key A & Key B & UID & UID & Key B & Key A \\
\hline 14 5E C1 3C 9A 15 5E C1 03 12 3C 9A 14 5E C1 3C 5E C1 03 12 5E C1 03 12 3C 9A 14 5E C1 3C 9A 15 \\
\hline
\end{tabular}

\section{Gambar 7. Mekanisme Penyusunan Key 256 Bit}

Selanjutnya, key 256 bit yang telah terbentuk tersebut digunakan untuk melakukan enkripsi data pada Tabel 2, sehingga cipherteks yang dihasilkan adalah F3 24 0D 88 DB 83 26 7F 8333 C7 5C F9 
68 0C CC BB CF B0 63 C9 8638 C6 AC 22 16 1F 94 F6 8A F8 60 A1 A8 1755 ED 0D 8F 772620 ED F3 2F CD 59. Cipherteks yang dihasilkan dari proses enkripsi menggunakan key 256 bit juga mempunyai panjang data sebesar 48 byte, sama seperti key dengan ukuran lainnya. Hal ini menunjukkan bahwa panjang key tidak mempengaruhi panjang cipherteks. Panjang data hanya mengalami perubahan dari plainteks menjadi cipherteks, yaitu dari 40 byte menjadi 48 byte.

Untuk mengetahui kinerja algoritma yang diusulkan, skenario pengujian dilakukan pada data sepanjang 40 byte dengan menggunakan semua key yang telah didefinisikan, yaitu key berukuran 128 bit, 192 bit, dan 256 bit. Pengujian dilakukan untuk memperoleh informasi mengenai durasi penulisan data ke dalam kartu, durasi pembacaan data dari kartu, dan proses generate key dari UID setiap kartu. Hasil pengujian algoritma menggunakan key 128 bit, 192 bit, dan 256 bit masing-masing ditunjukkan pada Tabel 3 sampai dengan Tabel 5. Durasi penulisan data dihitung mulai dari proses enkripsi 40 byte data (plainteks) sampai dengan penyimpanan data ke dalam smart card, sedangkan durasi pembacaan data dihitung mulai dari proses pembacaan data pada smart card sampai dengan proses dekripsi data.

Tabel 3. Hasil Pengujian Menggunakan Key 128 bit

\begin{tabular}{ccccc}
\hline No & UID & Key & $\begin{array}{c}\text { Durasi } \\
\text { Penulisan } \\
\text { Data (ms) }\end{array}$ & $\begin{array}{c}\text { Durasi } \\
\text { Pembacaan } \\
\text { Data (ms) }\end{array}$ \\
\hline 1 & A9C31CE5 & 145EC13C9A15A9C31CE55EC103123C9A & 73 & 91 \\
2 & 290DA66E & 14E66AD09215290DA66EE66A0312D092 & 71 & 89 \\
3 & 3206C64D & 14D46C6023153206C64DD46C03126023 & 70 & 91 \\
4 & FA8FA015 & 14510AF8AF15FA8FA015510A0312F8AF & 71 & 89 \\
5 & 0B7E7C22 & 1422C7E7B0150B7E7C2222C70312E7B0 & 71 & 87 \\
\hline \multicolumn{4}{c}{ Rata-rata } & 71.2 \\
\hline
\end{tabular}

Tabel 3 menunjukkan hasil enkripsi dan dekripsi pada smart card menggunakan key 128 bit yang diuji cobakan pada lima kartu yang berbeda. Berdasarkan Tabel 3 tersebut, diketahui bahwa proses pembacaan data membutuhkan waktu lebih lama dibandingkan dengan proses penulisan data, yaitu waktu rata-rata sebesar $71.2 \mathrm{~ms}$ untuk penulisan data dan $89.4 \mathrm{~ms}$ untuk pembacaan data. Hal ini dikarenakan pada proses pembacaan terdapat proses dekripsi data yang membutuhkan waktu komputasi lebih tinggi.

Tabel 4. Hasil Pengujian Menggunakan Key 192 bit

\begin{tabular}{cclcc}
\hline No & UID & \multicolumn{1}{c}{ Key } & $\begin{array}{c}\text { Durasi } \\
\text { Penulisan } \\
\text { Data (ms) }\end{array}$ & $\begin{array}{c}\text { Durasi } \\
\text { Pembacaan } \\
\text { Data (ms) }\end{array}$ \\
\hline 1 & A9C31CE5 & $\begin{array}{l}\text { 145EC13C9A155EC103123C9A5EC10312 } \\
\text { 3C9A145EC13C9A15 }\end{array}$ & 73 & 87 \\
2 & 290DA66E & $\begin{array}{l}\text { 14E66AD09215E66A0312D092E66A0312 } \\
\text { D09214E66AD09215 }\end{array}$ & 69 & 86 \\
3 & 3206C64D & $\begin{array}{l}\text { 14D46C602315D46C03126023D46C03126 } \\
\text { 02314D46C602315 }\end{array}$ & 70 & 88 \\
4 & FA8FA015 & $\begin{array}{l}\text { 14510AF8AF15510A0312F8AF510A0312 } \\
\text { F8AF14510AF8AF15 }\end{array}$ & 70 & 87 \\
5 & 0B7E7C22 & $\begin{array}{l}\text { 1422C7E7B01522C70312E7B022C70312E } \\
\text { 7B01422C7E7B015 }\end{array}$ & 72 & 92 \\
\hline \multicolumn{2}{c}{ Rata-rata } & 70.8 & 88 \\
\hline
\end{tabular}

Hasil pengujian pada Tabel 4 tetap menggunakan lima kartu yang sama seperti pada pengujian sebelumnya, hal yang membedakan adalah key yang digunakan yaitu mempunyai panjang 192 bit. Berdasarkan hasil pengujian pada Tabel 4 tersebut, diperoleh waktu rata-rata penulisan data sebesar $70.8 \mathrm{~ms}$ dan pembacaan data sebesar $88 \mathrm{~ms}$. 
Tabel 5. Hasil Pengujian Menggunakan Key 256 bit

\begin{tabular}{ccccc}
\hline No & UID & \multicolumn{1}{c}{ Key } & $\begin{array}{c}\text { Durasi } \\
\text { Penulisan } \\
\text { Data (ms) }\end{array}$ & $\begin{array}{c}\text { Durasi } \\
\text { Pembacaan } \\
\text { Data (ms) }\end{array}$ \\
\hline 1 & A9C31CE5 & $\begin{array}{l}\text { 145EC13C9A155EC103123C9A145EC13C5 } \\
\text { EC103125EC103123C9A145EC13C9A15 }\end{array}$ & 74 & 91 \\
2 & 290DA66E & $\begin{array}{l}\text { 14E66AD09215E66A0312D09214E66AD0E } \\
\text { 66A0312E66A0312D09214E66AD09215 }\end{array}$ & 73 & 89 \\
3 & 3206C64D & $\begin{array}{l}\text { 14D46C602315D46C0312602314D46C60D } \\
\text { 46C0312D46C0312602314D46C602315 }\end{array}$ & 70 & 88 \\
4 & FA8FA015 & $\begin{array}{l}\text { 14510AF8AF15510A0312F8AF14510AF85 } \\
\text { 10A0312510A0312F8AF14510AF8AF15 }\end{array}$ & 72 & 87 \\
5 & 0B7E7C22 & $\begin{array}{l}\text { 1422C7E7B01522C70312E7B01422C7E722 } \\
\text { C7031222C70312E7B01422C7E7B015 }\end{array}$ & 71 & 87 \\
\hline \multicolumn{5}{c}{ Rata-rata } \\
\hline
\end{tabular}

Sama halnya dengan Tabel 3 dan Tabel 4, Tabel 5 merupakan hasil pengujian algoritma dengan menggunakan lima kartu yang berbeda dan key sepanjang 256 bit. Waktu rata-rata yang dibutuhkan untuk melakukan penulisan data sebesar $72 \mathrm{~ms}$ dan pembacaan data sebesar $88.4 \mathrm{~ms}$.

Dengan menggunakan lima kartu yang telah digunakan sebelumnya, skenario pengujian juga dilakukan untuk melakukan proses penulisan data dan pembacaan data tanpa adanya enkripsi dan dekripsi. Hasil pengujian ini ditunjukkan pada Tabel 6.

Tabel 6. Hasil Pengujian Tanpa Enkripsi dan Dekripsi

\begin{tabular}{cccc}
\hline No & UID & $\begin{array}{c}\text { Durasi Penulisan } \\
\text { Data }(\mathbf{m s})\end{array}$ & $\begin{array}{c}\text { Durasi Pembacaan } \\
\text { Data }(\mathbf{m s})\end{array}$ \\
\hline 1 & A9C31CE5 & 71 & 87 \\
2 & 290DA66E & 70 & 87 \\
3 & 3206C64D & 69 & 87 \\
4 & FA8FA015 & 73 & 87 \\
5 & 0B7E7C22 & 71 & 88 \\
\hline & Rata-rata & 70.8 & 87.2 \\
\hline
\end{tabular}

Pada Tabel 6, hasil pengujian menunjukkan bahwa waktu rata-rata yang diperlukan untuk melakukan penulisan dan pembacaan data tanpa proses enkripsi dan dekripsi cenderung lebih kecil dibandingkan dengan waktu rata-rata yang diperlukan ketika terdapat proses enkripsi dan dekripsi, yaitu sebesar $70.8 \mathrm{~ms}$ untuk penulisan data dan $87.2 \mathrm{~ms}$ untuk pembacaan data. Walaupun demikian, perbedaan waktu yang diperlukan untuk proses baca dan tulis data ketika menggunakan enkripsi tidak terlalu jauh berbeda dengan proses baca dan tulis data tanpa enkripsi, yaitu sekitar 1 sampai dengan 2 ms. Hal ini tentunya tidak sebanding dengan keuntungan yang diberikan oleh penggunaan proses enkripsi data menggunakan algoritma AES. Selain dilakukan pengamanan pada data, mekanisme pengamanan lainnya juga dilakukan di sisi smart card dengan memanfaatkan UID. Dengan demikian, antara satu kartu dengan kartu lainnya akan mempunyai key yang berbeda, serta proses penulisan dan pembacaan data tidak membutuhkan waktu yang terlalu lama.

\section{Kesimpulan}

Berdasarkan hasil pengujian yang telah dilakukan, proses enkripsi dan dekripsi data pada smart card menggunakan algoritma AES terbukti dapat diandalkan karena terdapat mekanisme penggunaan key yang bersifat dinamis, yaitu pembentukan key berdasarkan UID dari setiap smart card. Dengan demikian, meskipun AES termasuk algoritma yang bersifat symmetric, namun adanya key dinamis ini menjadikan key yang digunakan setiap kartu menjadi berbeda-beda dan sulit untuk ditebak. Tentunya mekanisme ini menjadi sangat bermanfaat ketika smart card digunakan untuk aplikasi-aplikasi yang di dalamnya terdapat informasi yang bersifat rahasia. Penambahan enkripsi data menggunakan AES 
menjadikan data lebih aman, namun waktu yang diperlukan untuk proses penulisan dan pembacaan data pada smart card menjadi semakin bertambah. Hal ini dikarenakan setelah dilakukan enkripsi, panjang data yang awalnya 40 byte (plainteks) akan bertambah menjadi 48 byte (cipherteks) dan menyebabkan durasi penulisan dan pembacaan data menjadi sedikit lebih lama dibandingkan dengan tanpa adanya proses enkripsi. Waktu rata-rata yang diperlukan untuk melakukan penulisan dan pembacaan data dengan adanya enkripsi sekitar $2 \mathrm{~ms}$ lebih lama dibandingkan dengan tanpa adanya enkripsi. Selisih waktu tersebut tidaklah berarti jika dibandingkan dengan keamanan yang diperoleh ketika digunakan mekanisme pengamanan data menggunakan algoritma AES dan key dinamis berdasarkan UID setiap smart card. Setelah proses enkripsi data, ukuran plainteks biasanya akan cenderung membesar ketika menjadi cipherteks, sehingga dapat mempengaruhi waktu komputasi apabila ukuran data yang disimpan di dalam smart card cukup besar. Oleh karena itu, pada penelitian berikutnya, mekanisme kompresi menggunakan algoritma Huffman akan dilakukan untuk memperkecil ukuran cipherteks tanpa mengubah isi data yang tersimpan di dalam smart card.

\section{Referensi}

[1] H. Taherdoost, "Appraising the Smart Card Technology Adoption: Case of Application in University Environment," Procedia Eng., vol. 181, pp. 1049-1057, 2017.

[2] D. Priyasta, W. Cesar, Y. Susanti, and J. Junde, "Java Card Approach to Emulate The Indonesian National Electronic ID Smart Cards," Sci. J. Informatics, vol. 5, no. 2, pp. 224234, 2018.

[3] M. Akbar and I. Effendy, "Implementasi Aplikasi Kehadiran Perkuliahan di Kelas Menggunakan Pembaca RFID pada E-KTP,” J. Ilm. Matrik, vol. 19, no. 2, pp. 151-160, 2017.

[4] L. Miliani, M. S. Purwanegara, and M. T. D. Indriani, "Adoption Behavior of E-Money Usage," Inf. Manag. Bus. Rev., vol. 5, no. 7, pp. 369-378, 2013.

[5] Pranoto and S. S. Salsabila, "Eksistensi Kartu Kredit dengan Adanya Electronic Money (EMoney) Sebagai Alat Pembayaran yang Sah,” J. Priv. Law, vol. 6, no. 1, pp. 24-33, 2018.

[6] R. E. Rahmawati and M. R. Maika, "Penerapan Model UTAUT terkait akseptasi mahasiswa terhadap Cashless Payment di masa Pandemi COVID-19," J. Ekon. Mod., vol. 17, no. 1, pp. 114, 2021.

[7] B. W. Harimurti, W. Kurniawan, and H. Nurwarsito, "Sistem Pengelolaan Parkir Dengan NFC," J. Pengemb. Teknol. Inf. dan Ilmu Komput., vol. 2, no. 6, pp. 2038-2045, 2018.

[8] D. I. Putra and W. Syahputra, "Sistem Pembayaran Parkir Menggunakan Near Field Communication Berbasis Android dan Teknologi Internet of Things," J. Nas. Teknol. dan Sist. Inf., vol. 3, no. 1, pp. 153-164, 2017.

[9] H. Setiadi, Y. Priyandari, and S. I. Cahyono, "Implementation of Parking System Based on Radio Frequency Identification (RFID) at the Faculty of Engineering Sebelas Maret University," ITSMART J. Ilm. Teknol. dan Inf., vol. 6, no. 1, pp. 39-44, 2017.

[10] S. A. Utomo, D. Utomo, and B. W. Yohanes, "Sistem e-money berbasis Contactless Smartcard dengan Teknologi RFID," Techné J. Ilm. Elektrotek., vol. 15, no. 1, pp. 67-75, 2016.

[11] Ratnadewi, R. P. Adhie, Y. Hutama, J. Christian, and D. Wijaya, "Implementation and performance analysis of AES-128 cryptography method in an NFC-based communication system," World Trans. Eng. Technol. Educ., vol. 15, no. 2, pp. 178-183, 2017.

[12] B. Padmavathi and S. R. Kumari, "A Survey on Performance Analysis of DES, AES and RSA Algorithm along with LSB Substitution Technique," Int. J. Sci. Res., vol. 2, no. 4, pp. 170$174,2013$.

[13] Laurentinus, H. A. Pradana, D. Y. Sylfania, and F. P. Juniawan, "Perbandingan kinerja RSA dan AES terhadap kompresi pesan SMS menggunakan algoritme Huffman," J. Teknol. dan Sist. Komput., vol. 8, no. 3, pp. 171-177, 2020.

[14] Noprianto and V. N. Wijayaningrum, "End to End Enkripsi Menggunakan Advanced Encryption Standard pada Perangkat Internet of Things," J. Sist. Inf. dan Bisnis Cerdas, vol. 14, no. 2, pp. 98-107, 2021.

[15] A. M. Sison, B. T. Tanguilig, B. D. Gerardo, and Y. C. Byun, "Implementation of Improved DES Algorithm in Securing Smart Card Data," in Computer Applications for Software Engineering, Disaster Recovery, and Business Continuity, Berlin, Heidelberg: Springer, 2012, 
pp. 252-263.

[16] N. Aleisa, "A comparison of the 3DES and AES encryption standards," Int. J. Secur. its Appl., vol. 9, no. 7, pp. 241-246, 2015.

[17] H. A. Darwito, M. Yuliana, and R. Soelistijorini, "Implementasi Algoritme 3DES pada Sistem Sharing Electronic Health Record (EHR) Berbasis Cloud," J. Nas. Tek. Elektro dan Teknol. Inf., vol. 6, no. 3, pp. 284-290, 2017.

[18] F. Maqsood, M. Ahmed, M. M. Ali, and M. A. Shah, "Cryptography: A Comparative Analysis for Modern Techniques," Int. J. Adv. Comput. Sci. Appl., vol. 8, no. 6, pp. 442-448, 2017.

[19] H. O. Alanazi, B. B. Zaidan, A. A. Zaidan, H. A. Jalab, M. Shabbir, and Y. Al-Nabhani, "New Comparative Study Between DES, 3DES and AES within Nine Factors," J. Comput., vol. 2, no. 3, pp. 152-157, 2010.

[20] A. Y. Ananta, Noprianto, and V. N. Wijayaningrum, "Desain Sistem Smart Attendance Menggunakan Kombinasi Smart Card dan Sidik Jari," Sistemasi, vol. 9, no. 3, pp. 480-492, 2020. 